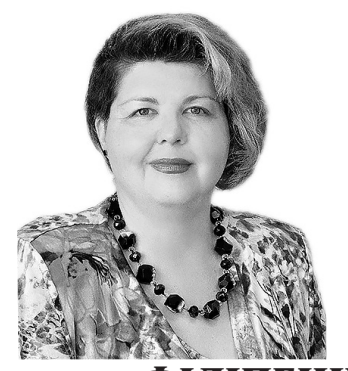

\title{
КРИМІНОЛОГІЧНА ДІЯЛЬНІСТЬ І ПИТАННЯ ПРАВОВОГО ВИХОВАННЯ НАСЕЛЕННЯ
}

ФІЛІІЕНКО Наталія Свгенівна - кандидат юридичних наук, доцент (доцент кафедри права Національного аерокосмічного університету ім. М. С. Жуковського «Харківський авіаційний інститут»)

Orcid:https://orcid.org/0000-0001-9469-3650

УДК 343.9

DOI 10.32782/LAW.2020.3.23

Вступ
Співробітництво правоохоронних органів із засобами масової інформації (далі - 3МІ), як показує практика, приносить в більшості випадків позитивні результати.

У сучасних умовах, що характеризуються різким загостренням криміногенної обстановки, взаємодія поліції, інших силових структур з мас-медіа вимагає негайної активізації. При цьому необхідно зосереджувати зусилля на особливо гострих напрямках, використовуючи найбільш ефективні форми i методи співпраці.

Якщо брати суто професійний аспект, то посилення співпраці зі ЗМІ прямо випливає iз вимог законів України: «Про державну підтримку засобів масової інформації та соціальний захист журналістів», «Про доступ до публічної інформації, «Про друковані засоби масової інформації (пресу) в Україні», «Про інформаційні агентства», «Про інформацію», «Про Національну раду України 3 питань телебачення і радіомовлення», «Про порядок висвітлення діяльності органів державної влади та органів місцевого самоврядування в Україні засобами масової інформації», Закон України «Про телебачення і радіомовлення», «Про телекомунікації» тощо. Так, Закон України «Про Національну поліцію» [1] прямо говорить про те, що громадська думка є головним мірилом ефективності діяльності органів поліції. При цьому головними завданнями вважаються: оперативність в діяльності підрозділів інформації і громадських зв'язків; виперед- ження в доведенні до населення правдивої та об'єктивної інформації про дії поліції; встановлення ефективних форм взаємодії 3 усіма $3 \mathrm{MI}$.

Аналіз останніх публікацій

Хоча окремі аспекти протидії злочинності, організації і здійснення кримінологічної діяльності висвітлені у працях таких вітчизняних та зарубіжних вчених, як О.М. Бандурки, С.С. Босхолова, М.Г. Вербенського, Е.О. Гладкової, В.В. Голіни, O.I. Гурова, О.М. Джужі, А.П. Закалюка, В.І. Кнорринга, О.Г. Колба, М.В. Корнієнка, О.М. Костенка Б.І. Краснова, О.М. Аитвака, О.М. Аитвинова, А.А. Музики, Ю.В. Орлова, В.М. Плішкіна, А.В. Савченка, С.В. Слінька, ᄉ.I. Спиридонова, В.А. Тимошенка, П.А. Фріса, О.Н. Ярмиша, Х.П. Ярмакі та інших науковців, роль 3МІ у цій діяльності не здобула належної уваги.

Відтак, з одного боку, визначення ролі засобів масової інформації у системі кримінологічної діяльності, а з іншого - способи взаємодії 3 ними 3 боку правоохоронних органів та інших владних інституцій, мають високий ступінь актуахьності.

Метою дослідження є визначення ролі ЗМІ у сфері кримінологічної діяльності, визначення можливостей співпраці у даній сфері та ідентифікація проблем, що виникають в межах такої співпраці. Само собою зрозуміло, що для виправлення становища повинні бути використані всі можливості, 
включаючи запозичення зарубіжного досвіду. Причому упор необхідно зробити на зусиллях превентивного, профілактичного характеру, на таких діях, які б перешкоджали спочатку розширенню негативних явищ, а потім сприяли їх зменшенню.

Звісно ж, що в цій справі найбільший ефект могло б дати щільна взаємодія правоохоронних структур з одного боку і $3 \mathrm{MI}-3$ іншого.

До речі, важливість широкого залучення мас-медіа до зусиль у протидії злочинності підкреслюється останнім часом фахівцями буквально всіх країн світу і найбільш авторитетних міжнародних організацій, включаючи ООН [2, с. 9]. При цьому зарубіжні експерти вказують, що система кримінального правосуддя може в даний час зіграти лише обмежену роль у запобіганні злочинності і тому пріоритетне місце відводять 3МI, маючи на увазі, в першу чергу, просвітницьку роботу, направлений на запобігання злочинності. При цьому особливо підкреслюють, що дана робота вкрай необхідна в цілях підвищення рівня освіченості [3].

Крім того, широко обговорюються питання довгострокового впливу 3МІ в цілому у встановленні стандартів поведінки, зміни споживчих переваг і т. Д. Деякі вчені стверджують, що більшість людей усвідомлюють такі поняття, як відхилення від норм поведінки і контроль, в першу чергу 3 телепередач. Інші дослідники вважають, що журналісти взагалі грають головну роль у формуванні уявлень про порядок, стабільність і зміни і впливають на практику самоконтролю, яка будується відповідно до цих уявлень [4].

Сьогодні практично всі визнають, що 3МI належить вирішальна роль в ознайомленні населення 3 найбільш значними факторами, у тому числі криміногенного штибу.

Питання полягає в тому, як впливають ці засоби на уявлення людей про злочинне. Переконані, якби всі виступи ЗМІ містили засудження злочинного, то це могло $б$ мати ефект, зворотний бажаному. Тому потрібно говорити всю правду, включаючи відомості, прямо протилежні по суті. Адже в іншому випадку люди побачить протиріччя між тим, що вони бачать у реальному житті, і тим, що їм розповідають у ЗМІ. Ми ж спостерігаємо майже повну негнучкість офіційної влади, які змушують журналістів проводити інформаційну політику тільки одностороннього характеру, в чому нібито міститься небезпека обмеження свободи думок. Ба більше, дійшло до того, що комусь 3 чиновників прийшло в голову заборонити ряд видань і фільмів, які розповідають про потойбічну історію, популярних пісень на відповідну тематику і т. п. Тож, де та грань, що поділяє інформацію на застереження і пропаганду. Ми думаємо, якщо є свобода інформації, то не повинно бути ніяких обмежень. Саме так свого часу сталось і з наркотиками, коли під приводом дотримання права на свободу інформації та демократичні волевиявлення вітчизняні 3МI виступили проти посилення антинаркотичних заходів в цілому і участі в цій справі преси.

Не треба мати спеціальних навичок, аби віднайти зараз інформацію про наркотики. Серед джерел найбільш доступної інформації про номенклатуру наркопрепаратів, їх придбання, виготовлення, використання i т. д. чільну роль у нас грають засоби масової інформації. Очевидним лідером є інтернет, за ним слідують такі комунікаційні канали, як телебачення, радіомовлення, відеопродукція, друк.

Молодь і студентство черпають відомості про наркотичні речовини 3 WEB-сторінок мережі інтернет, а деяка частина - в процесі комп'ютерних ігор. У громадських місцях, навчальних закладах, на дискотеках тощо молоді люди діляться адресами інформаційних джерел, тобто обмінюються відомостями.

Очевидно, що будь-яке адміністративне перекриття описаних вище каналів поки що технічно неможливо, з одного боку, в силу їх численності і різноманітності, а 3 іншого, через нестачу коштів для організації подібних заходів протидії. Тому теза про введення якоїсь «цензури» 3 боку влади, про яку йшлося вище, $є$ надуманою i, як вже згадувалося, використовується в явно зловмисних цілях.

Засоби масової інформації, з огляду на їх величезну щоденну аудиторію, можуть вне- 


\section{Кримінальне право, кримінальний процес та криміналістика}

сти істотний внесок у справу протидії 3лочинності.

Встановлюючи ділові контакти $з$ працівниками телебачення, радіо, газет, журналів, інтернет-видань і надаючи їм необхідну інформацію про стан криміногенної ситуації, необхідно домагатися, щоб в основі повідомлень лежала об'єктивність, а не сенсаційність. Цілком ймовірно, що саме прагнення до сенсацій, бажання кинути виклик суспільству і необхідність підвищити рейтинг і пояснюють той факт, що деякі телевізійні компанії, газети, інтернет-портали передають значно більше перекрученої інформації, ніж інформації, в якій розглядаються наслідки такої політики і пов'язана з цим шкода.

Використовуючи величезний потенціал ЗМІ слід проводити заходи у сфері профілактики і освіти [5, с. 150-154], спрямовані на об'єктивне інформування широкої громадськості, що сприятиме формуванню більш раціонального підходу до проблем і дозволить уникнути сенсаційності.

При цьому правоохоронцям слід враховувати, що представники ЗМІ, які спеціалізуються на кримінальних проблемах, повинні в них розбиратися. Для цього необхідно активно співпрацювати з:

- керівниками друкованих видань (газет, журналів і т. п.), інтернет-медіа, в яких створюються постійні рубрики 3 відповідних проблем;

- журналістами і кореспондентами, що спеціалізуються на зазначеній тематиці;

- адміністрацією регіону та органів місцевого самоврядування, яким слід запропонувати цикли передач із залученням правоохоронців, експертів, науковців, педагогів, психологів, медичних працівників і т. д.;

- громадськими лідерами, акторами, музичними та спортивними діячами, які пропагують нормальний спосіб життя.

Тактика, заснована на використанні засобів масової інформації, становить лише частину стратегії протидії злочинності.

у підготовчих матеріалах до Дев'ятого Конгресу ООН по боротьбі зі злочинністю та поводження зі злочинцями [6] пропонується ширше використовувати так званий «соціальний маркетинг», тобто сприяти шляхом надання матеріалів і порад поши- ренню позитивних поведінкових моделей. Використовувана при цьому методика [7, с. 74-77] може бути спрямована на проведення дискусій, поширення інформації, надання впливу на взаємини, систему цінностей і створення клімату, сприятливого для подолання зловживань і протиправних дій. Зовсім не обов' язково, щоб «соціальний маркетинг» сам по собі вів до зміни моделей поведінки, він може змінювати сприйняття, ставлення і думки, що також йде на користь антикримінальній моделі державної політики, іiї стратегіï і тактиці.

Що стосується поліції, то вона, як особливо підкреслюється в документах Дев'ятого Конгресу ООН, може відігравати важливу роль також у справі визначення характеру інформації для 3МІ. У багатьох країнах представники преси звертаються до поліції за відомостями про вчинені злочини. Форма надання поліцією відповідних відомостей часто визначає характер просування їх в суспільно-політичні кола і певною мірою реакцію населення на ту чи іншу подію і супутні обставини.

В принципі початковий етап пропагандистських дій добре знайомий майже кожному, адже це лише передача певної інформації в будь-якій формі (усній, письмовій, графічній, образотворчій і т. д.) [8, c. 61]. На жаль, найчастіше кампанія цим і обмежується, і тому їі ККД, як правило, буває досить невисокий, а то і взагалі нульовий (у тому випадку, якщо інформація залишиться, як то кажуть, під сукном). Якщо ж просування повідомлення носить сенсаційний відтінок, то його можуть підхопити, поширити інші, не причетні особи; хтось із них прокоментує, доповнить сам, хтось спотворить первинний матеріал до невпізнання. Захід почне розвиватися стихійно i може навіть призвести до протилежного, не запрограмованого результату (особливо, якщо до нього підключаться інтернет-боти [9]).

Щоб домогтися серйозного (цільового) результату, важливо кампанію заздалегідь спланувати і здійснити за задуманою схемою, в якій слід врахувати фактор часу (початок, розвиток, завершення кампанії), місце, передбачити паузи, підкріплення, 
коригування тощо. Для цього, як мінімум необхідні:

- власне інформація (первинна, розвиваюча, підкріплююча, заключна);

- засоби інформації, які гарантовано будуть брати участь у виконанні розробленого плану;

- зворотний зв'язок (збір та аналіз відомостей про вплив на громадськість просунутих матеріалів, їх подальше поширення серед населення).

Зі сказаного виходить, що здійснення ефективної пропагандистської кампанії вимагає ретельної підготовки, а також кваліфікованих виконавців. Ці дві умови взаємопов'язані і при відповідальному підході можуть бути дотримані у максимальній мipi.

Робота з реалізації акцій проводиться за тими ж параметрами, що викладені у попередній частині, і має лише регіональну специфіку.

Слід мати на увазі, що у невеликому місті, декількох населених пунктах при значній їх віддаленості один від одного особливу роль відіграють місцеве телебачення і радіо, менше - інтернет, майже не доступні друковані 3MI.

На місцях значно складніше, ніж на державному рівні, отримати необхідну інформацію, підібрати відповідні за задумом акції органи преси і головне, - там може не бути кваліфікованих співробітників. У зв’язку 3 цим розробку, планування і реалізацію акції в регіоні бажано проводити із залученням фахівців регіонального рівня, науковців (наприклад, в якості консультантів, використовуючи для цього телефонний або інший зв'язок).

3 іншого боку, в регіонах здійснення акцій є більш легкою справою, ніж на державному рівні. В окремому місті керівні працівники правоохоронних органів і преси, як правило, підтримують найтісніші повсякденні контакти і швидше знаходять спільну мову. Внаслідок частого спілкування вони можуть легше погоджувати акції і коригувати їх хід.

Необхідно відзначити і ту обставину, що в областях, регіонах, на прикордонних територіях вплив проведеної акції на населен- ня може бути більш значним, ніж у центрі, адже там дуже уважно ставляться до повідомлень місцевих 3МІ та виказують їм більшу довіру.

Якщо говорити про просвітницькі кампанії, то вони повинні проводитися постійно. Їх посилення або послаблення може бути пов'язано лише 3 особливостями сприйняття населенням, сезонними факторами (наприклад, літні канікули) та іншими моментами. У такої кампанії мають брати участь медики, науковці, вихователі, правоохоронні, експертні та інші держустанови, громадські організації, популярні діячі мистецтва і практично всі 3МI (телебачення, кіно, радіо, комп'ютерні мережі, реклама, наочна агітація і т. д.), а так само книговидання (книжкова продукція).

Однак оскільки в компетенцію правоохоронних органів не входить організація настільки широких кампаній (що, тим не менш можливо), розглянемо лише можливості специфічного характеру.

Пропагандистську кампанію 3 даної тематики, у тому числі на місцях, треба починати 3 загальної постановки завдання. Необхідно скласти докладний план, в якому визначити приблизний часовий період проведення заходу, задіяні сили, рядових виконавців і відповідальних за всю роботу керівників. У плані має бути чітко відображено, з яких джерел і коли надходить відповідна інформація, як обробляється і дозується, в яких формах просувається; які органи інформації, а також інші засоби, і коли підключаються до участі. Одночасно слід передбачити географію і час здійснення етапів, аналіз ефективності вже здійсненої роботи та відповідне коригування, зумовлене новими обставинами (успіх, неуспіх, перешкоди, несподіванки і т. п.).

Резюмуємо: для організації та проведення широкої пропагандистської діяльності необхідно врахувати велику кількість факторів, розраховувати кваліфікованими фахівцями і виконавцями, яких потрібно навчати і спрямовувати на цю роботу в повсякденному режимі.

Із наведеного вище, можемо зробити низку висновків. 


\section{Кримінальне право, кримінальний процес та криміналістика}

1. Криміногенна ситуація останнім часом суттєво ускладнилася через різні причини, у тому числі соціально-економічні.

2. В умовах погіршення криміногенної ситуації і обстановки все більшої актуальності набуває профілактична діяльність у даній сфері. Враховуючи, що засоби масової інформації у сучасному світі мають суттєвий вплив на погляди і свідомість суспільства, забезпечення тісної взаємодії правоохоронних органів зі ЗМІ є однією з передумов проведення ефективної кримінологічної діяльності. При цьому, слід вести мову саме про взаємодію, а не контроль, адже адміністративні заходи із цензурування інформації, скоріше за все, матимуть негативний ефект, 3 огляду на вільне поширення інформації у сучасному світі.

3. Інформаційні кампанії у 3МІ мають бути спрямовані передусім на об'єктивне, повне та правдиве інформування, а також сприяти формуванню позитивних поведінкових моделей, системи цінностей, орієнтованих на нормальний спосіб життя.

4. Підготовка інформаційних кампаній мають включати не лише підготовку інформаційних матеріалів, але й підбір ефективних каналів поширення, забезпечення дієвого зворотного зв'язку.

\section{Аітература}

1. Про Національну поліцію : Закон України. Відомості Верховної Ради. 2015. № 40-41. Ст. 379.

2. Прохорова М.ᄉ. Наркотизм: уголовно-правовое и криминологическое исследование. СПб.: Юридический центр Пресс, 2002. 287 c.

3. Негодченко О.В. Організаційноправові проблеми забезпечення прав i свобод людини під час розкриття злочинів, пов'язаних з наркобізнесом. Науковий вісник Юридичної академї Міністерства внутрішніх справ: Збірник наукових праць. 2003. Спеціальний випуск № 1 (13). С. 5-11.

4. Бугера О. І. Проблеми використання засобів масової інформації для запобігання злочинів серед неповнолітніх : автореф. дис. на здобуття наук. ступеня канд. юрид. наук : 12.00.08. Київ, 2006. - 20 с.
5. Абетка медіа/за загал. ред. В. Ф. Іванова; переклад з нім. В. Климченка. Київ : Академія української преси, Центр вільної преси, 2015. 177 с.

6. Жаровська Г.П. Міжнародно-правові засади боротьби з транснаціональною злочинністю: проблеми й перспективи. URL: http://intlawalmanac.net/v6/13.pdf (дата звернення 02.10.2020).

7. Журналістський фах: газетно-журнальне виробництво : навчальний посібник/ за ред. В. В. Різуна. 2-ге вид., перероб. і доп. Київ : Видавничо-поліграфічний центр «Київський університет», 2012. 352 с.

8. Пределы правового пространства свободы прессы (российские споры с участием СМИ в контексте мировой практики) : сборник статей. Юристъ за конституционнъе права и свободъг/сост., отв. ред. и авт. вступ. ст. А. К. Соболева. Москва : Новая юстиция, 2008. - 272 с.

9. Вільям Ф. Мережі і мережеві війни: майбутне терору, злочинності та бойових дій/за ред. Дж. Арквілли, Д. Ронфельдта. Iнбормачійний бюлетень Міжвідомчого науководослідного центру з проблем боротьби з організованою злочинністю. 2006. № 5. С. 52-61.

Filipenko Natalia

PhD in Law, Associate Professor (Associate Professor of Law, ME Zhukousky National Aerospace University "Kharkiv Aviation Institute")

CRIMINOLOGICAL ACTIVITY AND QUESTIONS OF PEOPLE LEGAL EDUCATION

The purpose of the paper is to examine role of mass media in combating crimes, together with the opportunities of cooperation between the police and the mass media in combating crimes and main problems arising from such cooperation. Results of the study allows us to draw several conclusions. Firstly, we underscore that there is a significant increase of crimes. Under these circumstances, prevention-oriented approach to combating crimes gains special significance. Secondly, role of the mass media in shaping public perceptions of certain issues makes them a necessary partner for the law enforcement agencies in deterring spread of crimes. Thirdly, there are significant 


\section{АНОТАЦІЯ}

у статті розглянуто роль засобів масової інбормациї у протидї злочинності, організаизї та здійсненні кримінологічної діяльності, а також проблеми, щзо виникають в рамках такой взаємодї в Украӥні. Зроблено висновок про важливість, передусім, превентивних заходів, направлених на обмеження можливостей вчинення злочинів та ключову роль засобів масової інформачиї у иій діяльності, передусім через організачію спільних з правоохоронними та іншими органами влади інбормаиійних кампаній.

Ключові слова: правоохоронні органи, засоби масової інбормациї, інбормаційні кампанї, злочинність, кримінологічна діяльність.

problems arising from the fundamentally different interests of the mass media and the police, which requires the latter to seek ways to align their activities. Still, we see cooperation as the only way to succeed, as administrative measures, such as censorship, will be largely coun- terproductive in the age of high availability of the information. Practical implications of the study lie in the recommendations for the activities of the police aimed at ensuring efficient cooperation with the mass media in organizing informational campaigns, promoting healthy lifestyle and so on. We stress upon necessity of the well-planned campaign, including not only careful preparation of the information, but also selection of the most efficient channels of dissemination and setting up of the feedback in order to objectively appraise their results and to allow a certain level of flexibility in adapting and adjusting these campaigns to the circumstances. We also underscore importance of careful selection of the partners in mass media, so that both sides of the partnership have a deep understanding of the issue they are working with. Lastly, we investigate features of the information campaigns on the local level.

Key words: law enforcement agencies, mass media, information campaigns, crimes, criminological activity. 